\title{
The succession dynamics of a macroalgal community after a flood disturbance in a tropical stream from São Paulo State, southeastern Brazil
}

\author{
CIRO CESAR Z. BRANCO ${ }^{1,3}$, LUIS HENRIQUE Z. BRANCO ${ }^{2}$, MAURÍCIO OSVALDO MOURA ${ }^{1}$ \\ and FERNANDO RODRIGO BERTUSSO ${ }^{1}$
}

(received: July 9, 2004; accepted: December 9, 2004)

\begin{abstract}
The succession dynamics of a macroalgal community after a flood disturbance in a tropical stream from São Paulo State, southeastern Brazil). The succession dynamics of a macroalgal community in a tropical stream (20 $58^{\prime} \mathrm{S}$ and $49^{\circ} 25^{\prime} \mathrm{W}$ ) was investigated after disturbance by a sequence of intensive rains. High precipitation levels caused almost complete loss of the macroalgal community attached to the substratum and provided a strong pressure against its immediate re-establishment. After this disturbance, a weekly sampling program from May 1999 to January 2000 was established to investigate macroalgal recolonization. The community changed greatly throughout the succession process. The number of species varied from one to seven per sampling. Global abundance of macroalgal community did not reveal a consistent temporal pattern of variation. In early succession stages, the morphological form of tufts dominated, followed by unbranched filaments. Latter succession stages showed the almost exclusive occurrence of gelatinous forms, including filaments and colonies. The succession trajectory was mediated by phosphorus availability in which community composition followed a scheme of changes in growth forms. However, we believe that deterministic and stochastic processes occur in lotic ecosystems, but they are dependent on the length of time considered in the succession analyses.
\end{abstract}

Key words - disturbance, macroalgae, rainfall, stream, succession, tropical

RESUMO - (Dinâmica sucessional de uma comunidade de macroalgas após forte enchente em um riacho tropical do Estado de São Paulo, Sudeste do Brasil). A dinâmica sucessional de uma comunidade de macroalgas em um riacho tropical (20 $58^{\prime}$ S e $49^{\circ} 25^{\prime}$ W) foi investigada após a ocorrência de um distúrbio promovido pela seqüência de chuvas intensas. Altos níveis de precipitação pluviométrica causaram quase completa perda da comunidade de macroalgas presas ao substrato e provocaram uma forte pressão contra o seu imediato reestabelecimento. Após este distúrbio, um programa de amostragens semanais, conduzido durante o período de maio/1999 a janeiro/2000, foi estabelecido para investigar a recolonização da comunidade de macroalgas. A comunidade sofreu forte alteração durante o processo de sucessão. O número de espécies variou de um a sete por amostragem. A abundância global da comunidade de macroalgas não revelou nenhum padrão de variação temporal consistente. Nos estágios sucessionais iniciais foi verificada uma forte predominância de tufos, seguido por filamentos não ramificados. Estágios sucessionais tardios mostraram ocorrência quase que exclusiva de formas gelatinosas, incluindo filamentos e colônias. A trajetória sucessional foi mediada pela disponibilidade de fósforo e a composição da comunidade seguiu um esquema de alterações segundo as formas de crescimento das espécies. Entretanto, acredita-se que tanto processos determinísticos quanto estocásticos ocorrem em ecossistemas lóticos, porém sendo dependentes da escala de tempo considerada na análise sucessional.

Palavras-chave - distúrbio, macroalgas, pluviosidade, riacho, sucessão, tropical

\section{Introduction}

It is widely recognized that current velocity acts as a regulatory agent of the nutritional resources available to algal communities in lotic ecosystems (Whitford 1960), because it reduces the distance between the environment and cell surface, allowing for more efficient uptake of nutrients and excretion of metabolic wastes. In addition,

1. Unesp/FCL, Departamento de Biologia, Av. Dom Antônio, 2100, 19800-000 Assis, SP, Brasil.

2. Unesp/Ibilce, Departamento de Zoologia e Botânica, Rua Cristovão Colombo, 226, 15054-000 São José do Rio Preto, SP, Brasil.

3. Corresponding author: czbranco@assis.unesp.br higher current velocities stimulate photosynthesis and facilitate immigration and subsequent colonization of periphytic algae (Ghosh \& Gaur 1998). However, the organisms that inhabit in running waters need mechanisms to avoid or resist mechanical stress caused by water flow (Gordon et al. 1992). Thus, several authors have suggested that the disturbance produced by current velocity is very important to the settlement and maintenance of the periphytic biomass in lotic ecosystems (Horner \& Welch 1981, Steinman \& McIntire 1986, Lamberti et al. 1991, Uehlinger et al. 1996).

The current velocity effect on periphytic communities could be amplified in periods when intensive 
precipitation greatly increases the water flow, causing floods and its harmful effects. In these cases, lotic biomass could be deeply affected or, in extreme situations, totally extinguished on a local scale. According to Lake (2000), flow disturbances can destroy preexisting habitats and create new ones that will be colonized and inhabited by a new biota, after the return of stability in flow conditions. Uehlinger et al. (1996) believe, in these circumstances, that the recovery of algal communities is dependent upon re-growth of persistent plant and to the establishment of those considered recolonizers.

When an ecological community is subjected to a strong perturbation (e.g. flooding), its subsequent dynamics of change is called succession (Tilman 1994). Steinman et al. (1992) focused on succession of stream algal communities as a trade off of carbon and phosphorus uptake ability versus growth form, showing real differences in nutrients acquisition capabilities from diverse thallus types. Robinson et al. (2000) found strong seasonal effects of disturbance on a lake outlet algal assemblage, suggesting the existence of a complex interplay between the timing of disturbance and the intraand inter-seasonal development sequence of periphyton communities on stony substrata.

The present study was carried out after the occurrence of an unusual sequence of strong rains in the region of Borá Stream, a well-studied tropical Brazilian stream. The rains produced intensive modification in habitat characteristics and, consequently, in macroalgal community structure. In order to gain insight into the succession process of this particular lotic ecosystem, we investigated the qualitative and quantitative succession alterations of the macroalgal community immediately after the occurrence of the disturbance. In addition, the role of selected variables was evaluated throughout the recolonization process.

\section{Material and methods}

The succession process of a stream macroalgal community was analyzed in Borá Stream, a third-order stream segment located in the municipality of Cedral $\left(20^{\circ} 58^{\prime} \mathrm{S}\right.$ e $49^{\circ} 25^{\prime}$ W), northwestern region of São Paulo State, southeastern Brazil. The sampling site was a $10 \mathrm{~m}$ length stream segment (Sheath \& Burkholder 1985, Necchi et al. 1995a) permanently established. The substratum within the selected section of the stream was predominantly composed of bedrock, followed by boulders, gravel and pebbles. A thin sand-clay layer was frequently observed covering the substratum. Data collected at a nearby weather station showed the occurrence of a strong rainy period $(850 \mathrm{~mm}$ of accumulated rainfall) before the flood.

The succession investigation started immediately after the flood event and the sampling site was visited weekly between 25 May 1999 and 12 January 2000, wich is the most favorable growth period for macroalgae in this region (Necchi \& Pascoaloto 1993, Branco \& Necchi 1997). All steps of recolonization were investigated and the sampling ended when the global abundance of community showed an expected decline due to a new seasonal rainy period.

Observations of the alterations in the macroalgal community throughout the succession period were made by means of the quadrat technique (Necchi et al. 1995b). Sampling units were circles of $25 \mathrm{~cm}$ in diameter $\left(\right.$ area $\left.=0.05 \mathrm{~m}^{2}\right)$. This shape was adopted to reduce the edge effect (Krebs 1989). The size of sampling units was chosen on the basis of preliminary tests and a previous investigation (Necchi et al. 1995b). Twenty-six sampling units were distributed along the width in each $1 \mathrm{~m}$ interval of the stream segment. The minimum statistically acceptable sampling size was estimated to be 25, according to the following equation: $n=(S / E . x)^{2}$; where $\mathrm{S}=$ standard-deviation, $\mathrm{E}=$ predetermined standard-error (0.05), $\mathrm{x}=$ mean (Southwood 1978).

Micro-environmental characteristics were noted in the sampling units. Algal presence and its respective percent cover on the substratum were visually estimated (Necchi 1993, Branco \& Necchi 1998a) with a Plexiglas view-box (bottom surface ca. $175 \mathrm{~cm}^{2}$ ). Current velocity was measured with a General Oceanics 2030R mechanical flow meter immediately below the water surface. This procedure was repeated at each $1 \mathrm{~m}$ interval in the sampling area, for a total of 10 measurements for each sampling date. Irradiance was determined with a Li-Cor LI-189 quanta meter and a Li-Cor LI-193SA spherical quantum sensor positioned at the stream bottom. Similar to current velocity, irradiance was measured in 10 replicates for each sampling date. Depth was measured with a ruler in each circle, while substratum type was recorded according to the particle size classes given by Gordon et al. (1992).

Water temperature, specific conductance, turbidity, $\mathrm{pH}$ and dissolved oxygen were measured from a water sample collected in midstream at 12:00 $\pm 1 \mathrm{~h}$ with the Horiba U-10 water checker, equipped with a multiple probe.

Nutrients (orthophosphate, ammonium, nitrate and nitrite) were analyzed using a Merck spectrophotometer, model SQ118 and specific Merck Spectroquant reagents. Measurements were made from a water sample collected at the midpoint of the sampling site and maintained in the freezer until the measurement (30 days after at maximum). Rainfall data were provided by the Regional Division of the Secretary of Agriculture, São Paulo State. Precipitation data for each sampling were considered as the total accumulated values in the six days before sampling.

The statistical analyses were carried out using the statistical package Statistica ('99 edition, StatSoft Incorporation). Correlations among species abundance, species frequency and stream variables throughout the 
succession period were determined by Pearson's r productmoment correlation coefficient (Sokal \& Rohlf 1981). To identify possible similar responses and then functional groups, a chronological cluster analysis was performed in a similarity matrix of sampling dates per species abundance, grouped with a UPGMA algorithm. Principal Component Analysis (PCA) of Digby \& Kempton (1987) was applied to reduce data dimension and to construct independent axes, to study the nature and magnitude of variation and covariation. Eigenvectors and eigenvalues were extracted from a similarity matrix of the species abundance. To minimize the effect of abundance discrepancies among species, the data were previously log transformed. Correlation among individual scores of axes derived from PCA and abiotic and biotic variables were analyzed to determine the contribution of these parameters to the variation pattern.

\section{Results}

Temporal variation of the environmental variables Precipitation followed the typical seasonal variation for the study region (figure 1A): low rainfall in winter (middle of the sampling period) and higher values and intensities during summer (ending of sampling period). Current velocity, depth and irradiance were in accordance with the expected data for the sampling period in the region (figures 1B-D). Current velocity varied from 19 to
$54 \mathrm{~cm} . \mathrm{s}^{-1}$, showing lower mean values at the peak of winter and higher at the beginning of summer. Depth was relatively constant throughout the sampling period, oscillating from $8-18 \mathrm{~cm}$. The temporal pattern of depth was very closely related to current velocity, showing higher values in summer and lower ones in winter. A positive correlation was found between these parameters $(r=0.496, p<0.01)$. Irradiance values were relatively high during the entire sampling period with minimum of $861 \mathrm{mmol} \cdot \mathrm{m}^{-2} \cdot \mathrm{s}^{-1}$ and maximum of $2,350 \mathrm{mmol} \cdot \mathrm{m}^{-2} \cdot \mathrm{s}^{-1}$. Extreme values were observed on the same sampling dates due to occasional rainy conditions (e.g., 16 September). All nutrients showed low values during the sampling period with occasional occurence of isolated peaks (figures $1 \mathrm{E}-\mathrm{H}$ ). Nitrate ranged from 0.1-3.0 mg. $\mathrm{L}^{-1}$, with the highest value occuring as an isolated peak in $29 \mathrm{July}$; ammonium showed, as a rule, values oscillating between $0.0-0.1 \mathrm{mg} . \mathrm{L}^{-1}$, with an expceptional highest value of $0.36 \mathrm{mg} . \mathrm{L}^{-1}$ occurring in 07 October; nitrite had very low values varying, almost all the time, between 0.01 and $0.05 \mathrm{mg} . \mathrm{L}^{-1}$, but in 11 November was observed an isolated peak with the highest value of $0.23 \mathrm{mg} . \mathrm{L}^{-1}$ and orthophosphate ranged from 0.2 to $0.34 \mathrm{mg} . \mathrm{L}^{-1}$, with the higher values occurring at the begginning of sampling periods, including two peaks, and the lower values at the final period.

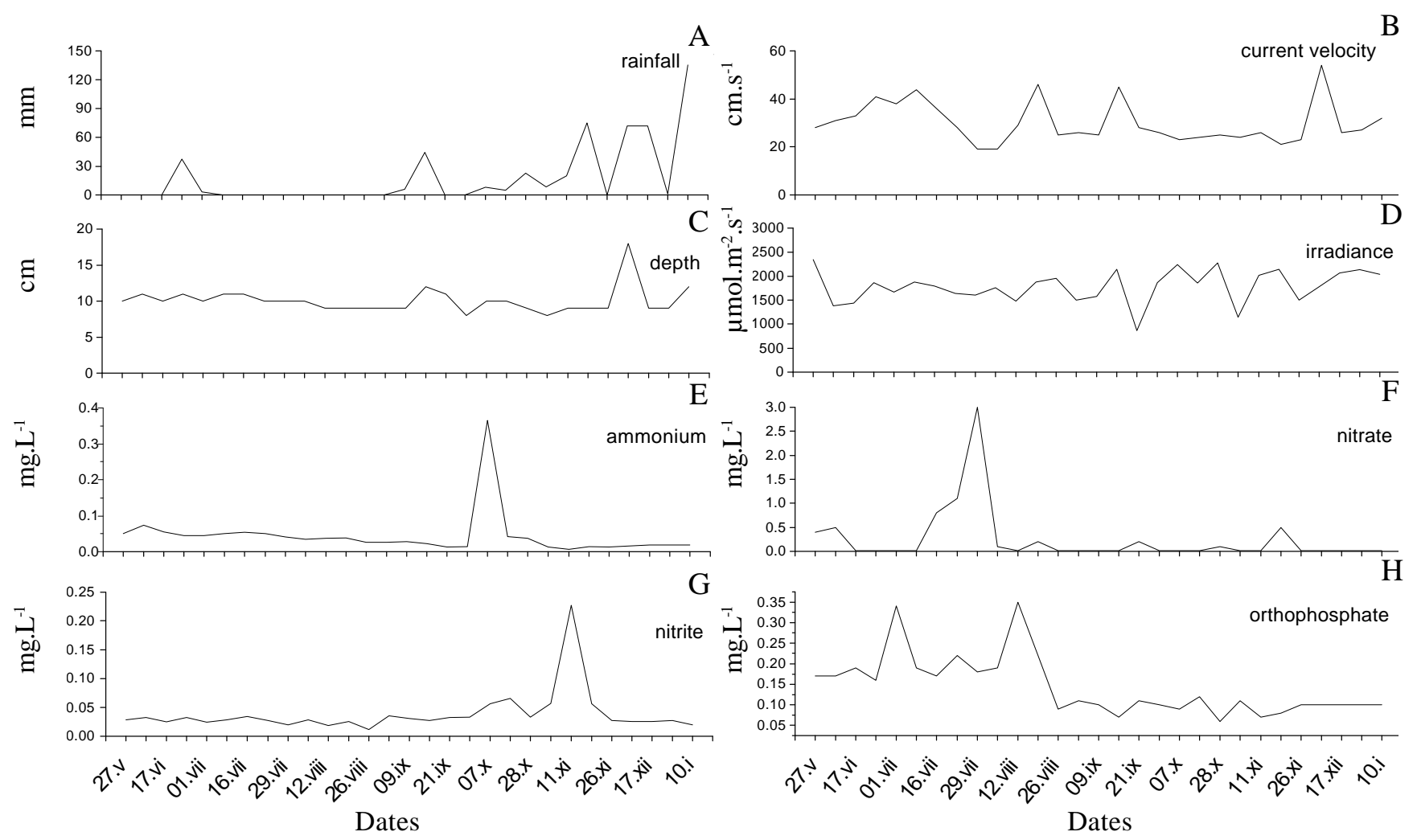

Figure 1. Variation of environmental parameters in the Borá stream from 25 May 1999 to 15 January 2000. 
Temporal variation of the macroalgal species - The Borá stream macroalgal community varied greatly during the succession process, including changes in total species number (species richness), global abundance (represented by percent cover of all species together) and species composition (table 1). During the sampling period, the species richness varied from one to seven per sampling date. At the beginning of the study, only Stigeoclonium amoenum Kützing was found, but the species numbers progressively increased to a maximum value at the end of the dry season. The species number decreased again at the end of the sampling program, when a new rainy season started, and only three species were recorded in the last sampling date (figure 2). Species richness (total species number) showed a significant and positive correlation with global abundance $(\mathrm{r}=0.39, \mathrm{p}<0.05)$ and a negative correlation with current velocity $(r=-0.44$, $\mathrm{p}<0.05)$.

The analysis of the macroalgal community global abundance during the study period did not reveal a consistent seasonal pattern of variation. However, it was observed the occurrence of low values at the beginning and at the end of the sampling period, with higher global abundance values in the middle of the period (figure 2). Global abundance was negatively correlated with precipitation $(\mathrm{r}=-0.45, \mathrm{p}<0.01)$ and depth $(\mathrm{r}=-0.44$, $\mathrm{p}<0.01)$.

Some species showed a more clear variation pattern in terms of abundance (percent cover of individual species), during the succession period. The green alga, Stigeoclonium amoenum, was recorded in Borá stream only in the first two samplings (figure 3).

The presence of "Chantransia" stage was observed for the first time on 24 April 1999, and was present until 21 October 1999 (figure 3). The abundance of this taxa was positively correlated with orthophosphate $(\mathrm{r}=0.59$, $\mathrm{p}<0.001$ ). The occurence of Spirogyra sp. (figure 3) was very similar to "Chantransia", only differing at the beginning (29 July 1999) and the end (11 November 1999) of establishment and maintenance of population (figure 3). The only significant correlation for this taxon was found between abundance and depth $(r=-0.40$, $\mathrm{p}<0.05)$.

Table 1. Macroalgae taxa in the Borá stream from 25 May 1999 to 12 January 2000.

\begin{tabular}{|c|c|}
\hline Taxa & Occurrence dates \\
\hline \multicolumn{2}{|l|}{ CYANOPROKARYOTA } \\
\hline Cylindrospermum minutissimum Collins & 28.X \\
\hline Microcoleus subtorulosus Gomont & 07.X \\
\hline Phormidium irriguum (Gomont) Anagnostidis \& Komárek & 17.VII, 01.VII, 29.VII, 02.IX, 21.IX, 30.IX, 21.X, 10.I \\
\hline \multicolumn{2}{|l|}{ CHLOROPHYTA } \\
\hline Chaetophora elegans (Roth) C. Agardh & $\begin{array}{l}\text { 23.VII, 09.IX, 16.IX, 21.IX, 30.IX, 21.X, 28.X,04.XI, 11.XI, } \\
\text { 18.XI, 26.XI, 17.XII, 22.XII, 10.I }\end{array}$ \\
\hline Microspora floccosa (Vaucher) Thuret & 05.VIII, 12.VIII \\
\hline M. stagnorum (Kützing) Lagerheim & 01.VII, 08.VII, 16.VII, 26.VIII, 28.X, 18.XI, 22.XII, 10.I \\
\hline \multicolumn{2}{|l|}{$\begin{array}{l}\text { Nitella furcata (Roxburgh ex Bruzelius) C. Agardh } \\
\text { emend R.D. Wood subsp. mucronata (A. Braun) }\end{array}$} \\
\hline R.D. Wood var. mucronata & $\begin{array}{l}\text { 23.VII, 29.VII, 26.VIII, 02.IX, 09.IX, 16.IX, 21.IX, 30.IX, 07.X, } \\
\text { 21.X, 11.XI, 18.XI, 26.XI, 17.XII }\end{array}$ \\
\hline Oedogonium sp. & 23.VII, 19.VIII, 02.IX, 07.X, 18.XI \\
\hline Stigeoclonium amoenum Kützing & 27.V, 10.VI, 08.VII \\
\hline Spirogyra sp. & $\begin{array}{l}\text { 29.VII, 05.VIII, 12.VIII, 19.VIII, 26.VIII, 02.IX, 09.IX, 16.IX, } \\
\text { 21.IX, 30.IX, 04.XI, 11.XI }\end{array}$ \\
\hline Tetraspora gelatinosa (Vaucher) Desvaux & 21.IX, 28.X, 04.XI, 11.XI, 18.XI, 26.XI, 12.XII, 22.XII, 10.I \\
\hline \multicolumn{2}{|l|}{ RHODOPHYTA } \\
\hline Batrachospermum delicatulum (Skuja) Necchi \& Entwisle & $\begin{array}{l}\text { 09.IX, 16.IX, 21.IX, 30.IX, 07.X, 21.X, 28.X, 04.XI, 11.XI, } \\
\text { 18.XI, 26.XI, 17.XII, 22.XII, 10.I }\end{array}$ \\
\hline "Chantransia" stage & $\begin{array}{l}\text { 24.VI, 01.VII, 08.VII, 16.VII, 23.VII, 29.VII, 05.VIII, 12.VIII, } \\
\text { 19.VIII, 26.VIII, 02.IX, 09.IX, 16.IX, 21.IX, 30.IX, 07.X, 21.X }\end{array}$ \\
\hline \multicolumn{2}{|l|}{ HETEROKONTOPHYTA } \\
\hline Vaucheria sp. & 16.IX \\
\hline
\end{tabular}






Dates

Figure 2. Variation of global abundance (A) and species number (B) in the Borá stream from 25 May 1999 to 15 January 2000. Columns represent the precipitation scaled according Y2 (right) axis.

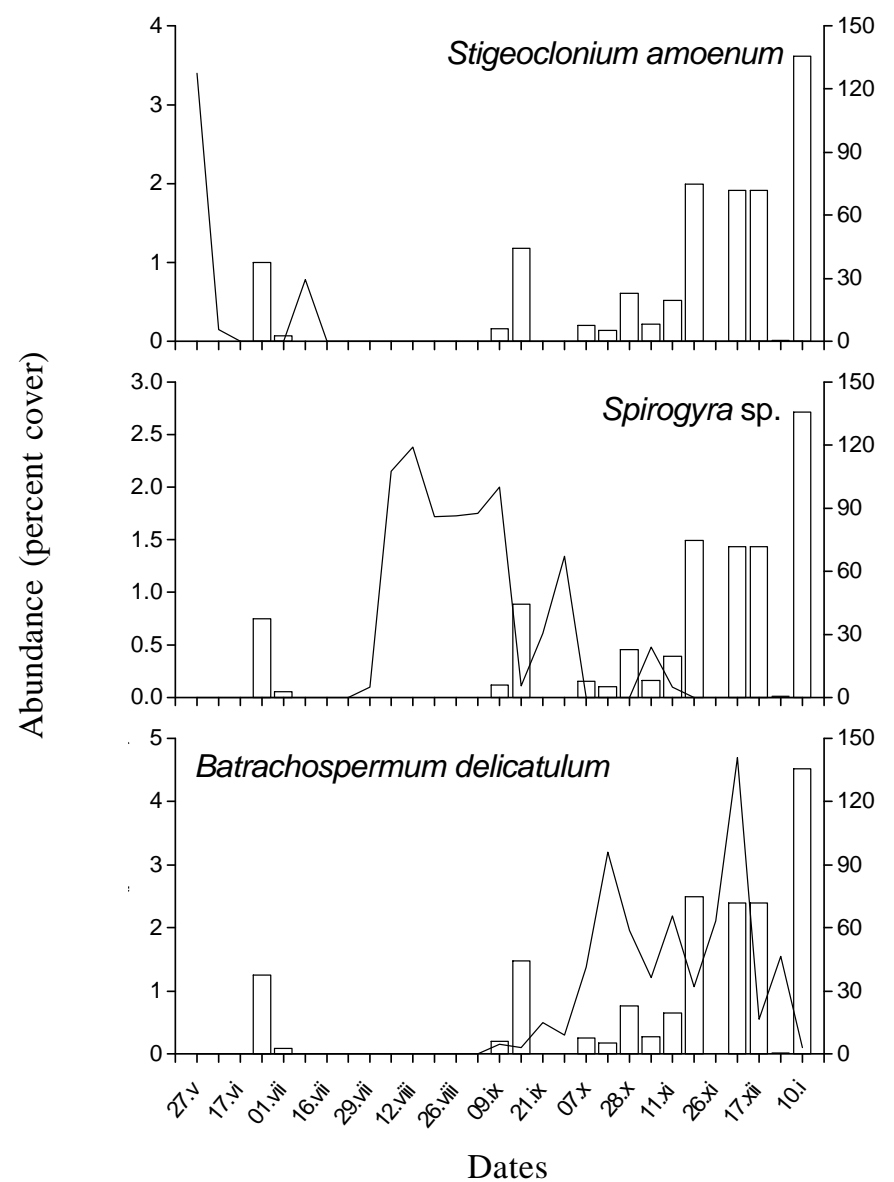

Three species (Chaetophora elegans (Roth) C. Agardh, Tetraspora gelatinosa (Vaucher) Desvaux and Batrachospermum delicatulum (Skuja) Necchi \& Entwisle) showed a similar general pattern in seasonal variation, occuring later in sucession than the previous taxa (figure 3). The abundance of these species revealed gradual increasing throughout the samplings, and then a decreasing at the end of the sampling period. Abundance of $C$. elegans was negatively correlated with orthophosphate $(\mathrm{r}=-0.38, \mathrm{p}<0.05)$ and depth $(\mathrm{r}=-0.43$, $\mathrm{p}<0.05)$. Abundance of $B$. delicatulum showed positive correlations with nitrite $(\mathrm{r}=0.52, \mathrm{p}=0.01)$ and negative with orthophosphate $(\mathrm{r}=-0.47, \mathrm{p}<0.05)$ and current velocity $(\mathrm{r}=-0.41, \mathrm{p}<0.05)$. Abundance of $T$. gelatinosa was negatively correlated with depth $(\mathrm{r}=$ $0.40, \mathrm{p}<0.05)$.

Cylindrospermum minutissimum Collins, Microcoleus subtorulosus Gomont, Microspora floccosa (Vaucher) Thuret, M. stagnorum (Kützing) Lagerheim, Oedogonium sp., Phormidium irriguum (Gomont) Anagnostidis \& Komárek and Vaucheria sp.

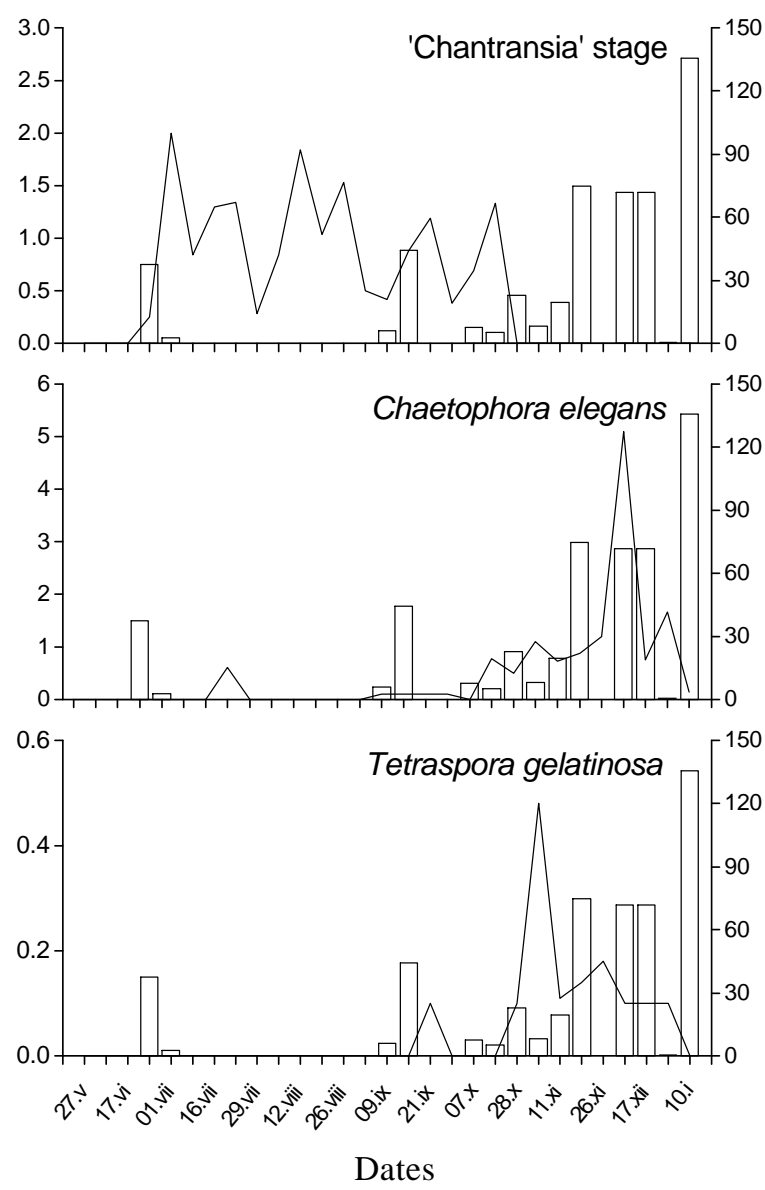

Figure 3. Variation of abundance of selected species (lines) in the Borá stream from 25 May 1999 to 15 January 2000. Columns represent the precipitation scaled according Y2 (right) axis. 
showed an irregular occurrence pattern with wide variation in abundance (table 1).

The classification of the most abundant macroalgae according to the growth form revealed the occurrence of four groups: i) Unbranched filaments - Spirogyra sp.; ii) Tufts - "Chantransia" stage and Stigeoclonium amoenum; iii) Gelatinous filaments - Batrachospermum delicatulum and iv) Gelatinous colony - Chaetophora elegans and Tetraspora gelatinosa. A clear correspondence was observed between the sequence of succession stages and the change in dominant growth form of the macroalgal community throughout the process (figure 4). In early succession stages, a strong predominance of tufts was seen, followed by unbranched filaments. Latter succession stages showed the almost exclusive occurrence of gelatinous forms, including filaments and colonies. Correlations among growth forms and environmental parameters revealed significant values for gelatinous forms with orthophosphate $(r=-0,86, p<0.001)$.

Cluster analysis of the sampling dates based on composition and abundance of macroalgal species in the succession pattern (Batrachospermum delicatulum, Chaetophora elegans, "Chantransia" stage, Spirogyra sp., Stigeoclonium amoenum and Tetraspora gelatinosa) revealed three distinct groups (figure 5). Group 1 comprised the early sampling dates, when species number and global abundance were low. Presence of "Chantransia" stage, as the only organism recorded, was a rule in this group. The 10 January 2001 sampling, the last field visit, was in group 1, but this result is consistent, because the macroalgal community

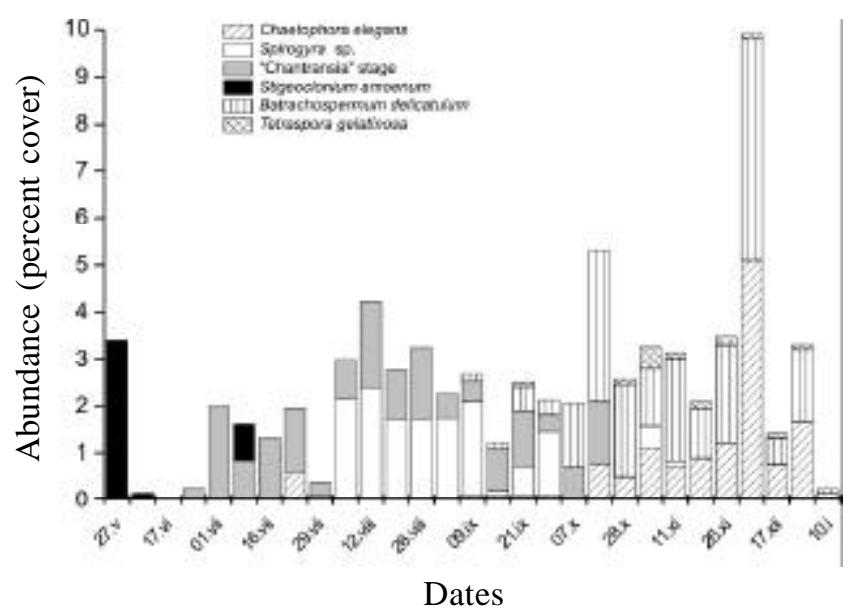

Figure 4. Seasonal variation of macroalgae occurrence with different thallus types in the Borá stream from 25 May 1999 to 15 January 2000.

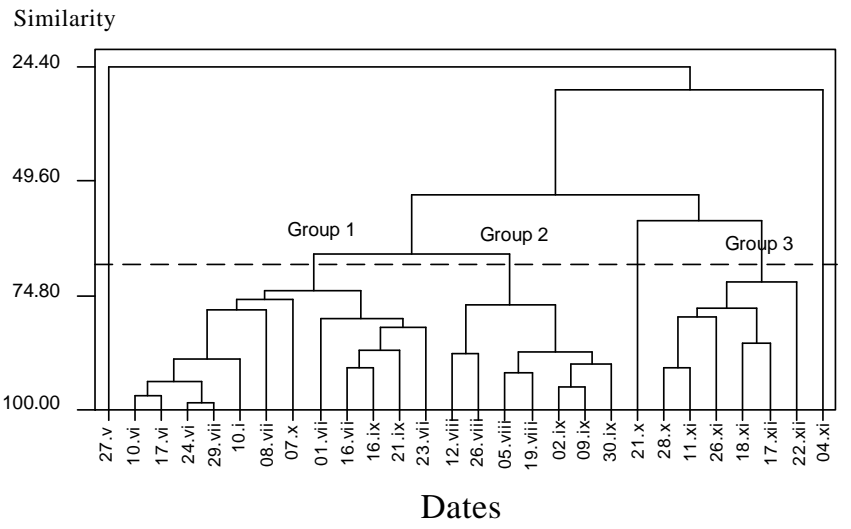

Figure 5. Cluster analysis of the samplings in the Borá stream from 25 May 1999 to 15 January 2000 according to the macroalgal occurrence and respective abundances.

global abundance at the end of the study showed low values, comparable to those observed at the beginning of the study. High abundance and predominance of "Chantransia" stage and Spirogyra sp. characterized the sampling dates found in group 2. In this group, the major abundance contribution of the filamentous green alga was clear. In group 3, the clustering of sampling dates from the final period of the study, in wich the occurrence of higher global abundances and species numbers were evident, is noteworthy.

The first three PCA axes accounted for $81.67 \%$ of the total variation (figure 6 , table 2). The first axis revealed two groups of species: one formed by positive scores and another formed by negative scores. The response to current velocity disturbance was not reflected on the first axis. Instead there was a strong influence of the abundance pattern linked to particular functional response to phosphate level in the water column (table 3). The second PCA axis was mainly influenced by the frequency of Stigeoclonium amoenum and seemed to reflect the distributional pattern of this species, resulting in $S$. amoenum temporaly separated from all other species. The third PCA axis showed no clear pattern, but probably reflects the spatial variation of microhabitat occupation, since strong correlations of this axis with particular stream variables, such as substratum and depth, were observed (table 3 ).

\section{Discussion}

A disturbance can be characterized by its temporal patterns and, therefore, the event observed in the Borá stream can be defined as a pulse disturbance, due to its well delimited action and short time interval (Lake 2000). 


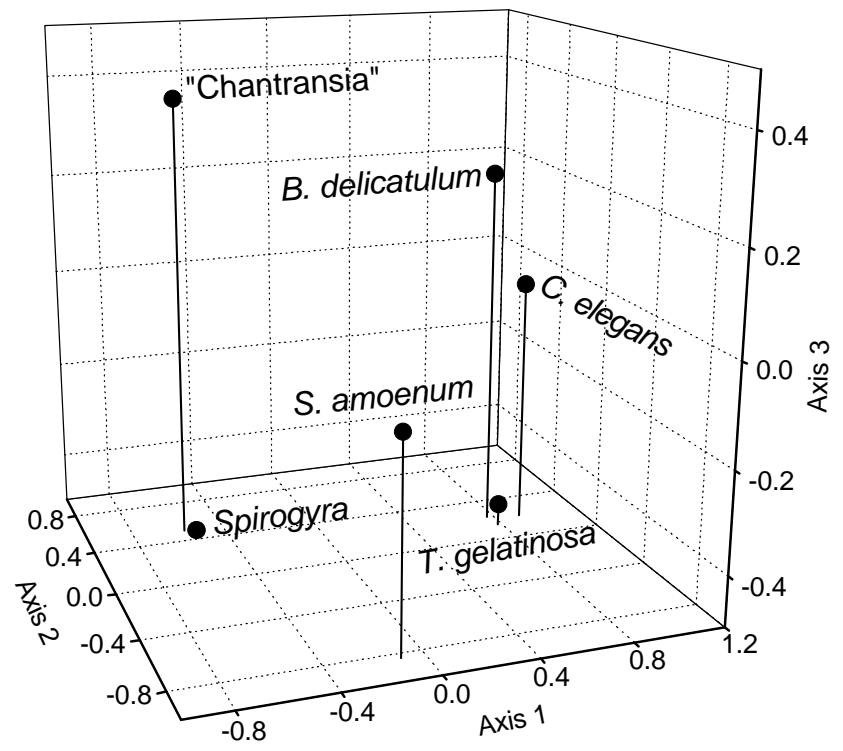

Figure 6. Principal Component Analysis (PCA) of the species found in the Borá stream from 25 May 1999 to 15 January 2000 on the basis of environmental variables and species percentage cover.

Table 2. Eingenvalues and explained variance of the three first axes for the Principal Component Analysis (PCA) of species collected in the Borá stream during succession process. $\mathrm{CE}=$ cumulative eingenvalues.

\begin{tabular}{lcccc}
\hline Axes & Eingenvalues & \% Total variance & CE & \% CE \\
\hline 1 & 2.79 & 46.47 & 2.79 & 46.47 \\
2 & 1.34 & 22.31 & 4.13 & 68.78 \\
3 & 0.77 & 12.88 & 4.90 & 81.67 \\
\hline
\end{tabular}

After the disturbance, the macroalgal community was greatly modified. The global abundance was strongly affected and showed extremely low values even during the most favorable growth period. Branco \& Necchi (1997, field data from 1992/1993) recorded much higher values of global abundance than those observed in the present study when researching the same seasonal period. The range in percent cover values reported in both studies are as follows: maximum $-50 \%$ and $7 \%$ and minimum $-5 \%$ and $0 \%$, respectively.

The modifications caused by flooding were less intense for species number and community composition than for global abundance. Branco \& Necchi (1998b) recorded 15 species throughout the seasonal period and 14 macroalgae were collected in the present study. Likewise, our data showed a relatively high similarity in the species composition when compared with Branco
Table 3. Significant correlations among PCA axes and species abundance and stream variables analyzed during the succession process in Borá stream.

\begin{tabular}{lccc}
\hline & AxIs 1 & AxIs 2 & AxIs 3 \\
\hline Species abundance & & & \\
Batrachospermum delicatulum & $0.753^{* * * *}$ & - & - \\
Tetraspora gelatinosa & $0.779^{*}$ & - & $-0.435^{*}$ \\
Chaetophora elegans & $0.921^{*}$ & - & - \\
Stigeoclonium amoenum & - & $0.823^{*}$ & - \\
"Chantransia" stage & $-0.582^{*}$ & $-0.464^{*}$ & $0.381^{*}$ \\
Spirogyra sp. & $-0.553^{*}$ & $-0.522^{*}$ & $-0.529^{*}$ \\
Stream variables & & & \\
Nitrite & $0.457^{* *}$ & - & - \\
Orthophosphate & $-0.485^{* *}$ & - & - \\
Ammonium & - & - & $0.379^{*}$ \\
Precipitation & $0.590^{* * * *}$ & - & - \\
Depth & - & $0.492^{* * *}$ & $0.512^{* *}$ \\
Rocky substratum & - & - & $0.369^{*}$ \\
\hline
\end{tabular}

$* \mathrm{p}<0.05, * * \mathrm{p}<0.01, * * * \mathrm{p}<0.001$

\& Necchi (1998b): nine of 14 macroalgae, collected in the present study, were also found previously. This evidence suggests a rapid macroalgal community recolonization, which is a fact also observed in other investigations (e.g. Fisher et al. 1982).

Branco \& Necchi (1997) described the strong influence of the filamentous green alga Stigeoclonium amoenum (as $S$. helveticum Vischer) on the global abundance for the community and a minor influence of all other species throughout the entire seasonal period. Conversely, our results revealed the occurrence of $S$. amoenum just at the early stages of the substratum recolonization and the presence of this species after flood disturbance must be primarily due to specimens that resisted the drag force. Certainly, the drastic reduction in S. amoenum abundance was crucial to the decreasing of the global abundance verified in the present study.

Lake (2000) assumed that changes in stream communities could be observed in response to disturbance promoted by alteration in current velocity. This author showed that floods, as well as droughts, could destroy habitat fragments and create new ones, and, consequently, allowing colonization by a new biota after the recovery of flow stability. This theoretical justification can explain the local replacement of Stigeoclonium amoenum by other species with higher relative abundances. A similar pattern was described by Benenati et al. (1998) in a study of the recolonization of phytobenthos in a regulated desert stream after an experimental drought period. The authors showed that 
changes in water flow were responsible for the damaging effects on species biomass and density and observed a significant modification in the species composition following water flow fluctuation.

The duration of the recovery process in a stream community after disturbance can be quite variable (Fisher 1983), and several environmental characteristics, such as local refuge, inoculation potential from adjacent regions and stream conditions after disturbance must be considered. Lamberti et al. (1991) observed, during recolonization process in a flood perturbed stream, an immediate decrease in global abundance of the benthic algal community followed by rapid increase. According to the authors, the disturbance promoted extensive environmental changes that resulted in higher light availability and an increase in local primary production. A similar improvement of macroalgal community biomass after disturbance was not observed in this study and other factors such as flood intensity, refuge availability and/or presence of new colonizers were probably acting in the Borá stream.

Steinman et al. (1992) evaluated the relationship between superficial area and volume of several growth forms, correlating these findings with carbon and phosphorus uptake efficiency. The results showed that branched filaments had higher efficiency in phosphorus acquisition, followed by unbranched filaments, prostate thalli and gelatinous forms. The results of the present study in Borá stream agree with Steinman's et al. (1992) data. At the beginning of the sampling program, phosphorus concentration showed relatively higher values than those observed in late stages, probably due to allochthonous input of nutrients after the rain. Consequently, filamentous and tuft growth forms, with more capacity for phosphorus absorption, were dominant in this successional stage. Mucilaginous species, considered less efficient in nutrient uptake (Steinman et al. 1992), were present with maximum abundance in the late samplings, when the phosphorus levels were less. Lock et al. (1984) suggested that the presence of mucilage could function as an orthophosphate absorption site, becoming a donator of the nutrient to algal cells when the resource is scarce. This property could allow for competitive advantage of gelatinous species, when the source of inorganic phosphorus is limited in the environment. The correlation data of gelatinous and filamentous forms with orthophosphate confirmed this hypothesis. In addition, PCA analysis indicated that the global abundance throughout the succession process was strongly linked to differential functional responses to environmental phosphorus levels. The results indicated that the sequence of alterations in community composition complied with a growth form scheme of changes according to the different life histories of the species.

Several studies consider the succession in lotic ecosystems as a stochastic event (Fisher 1983, Lake 2000). This proposition is based on the argument that the apparently occasional colonization and the unexpected character of the biotic changes do not allow the construction of succession models considering long time intervals and growth forms (Steinman et al. 1992), and, consequently, the proposition of a deterministic succession pattern is not admitted. On the other hand, McCormick \& Stevenson (1991) consider seasonal succession as a deterministic process based on the argument that interspecific differences in the life cycle and autogenic modifications in lotic environment result in predictable changes in community structure throughout time. According to the authors, allogenic factors (e.g. irradiance and temperature) certainly regulate the seasonal succession of benthic algae, but the generation time of these organisms are shorter than the seasonal frequency of determined allogenic factors (e.g. rain, fire or drought). Steinman et al. (1992) comment that under relatively stable environmental conditions and considering limited time intervals, it is possible to predict a temporal succession trajectory influenced by growth form. We believe that both processes can be found in lotic ecosystems, but they are dependent on the time interval considered in the succession analyses. Several studies indicate that the final result of the process can be predictable (or deterministic) in short-time intervals, if unexpected environmental pressures do not occur. In contrast, longtime intervals allow for the possibility of unexpected events that characterize the process as stochastic.

More studies of the succession in lotic ecosystems are desirable, mainly those involving different temporal perspectives, in wich the investigation focuses detailed analyses of the succession trajectories by short and long time intervals. These data are fundamental to construct an unifying concept of succession for lotic ecosystems. Complementary aspects such as refuge analysis, formfunction relationships of organisms and patchy distribution must also be evaluated, mainly in tropical regions, to improve the theoretical basis for the understanding of the relations between the environment and its biotic components.

Acknowledgments - This research was supported by a Fapesp grant-in-aid (1999/09054-7) to L.H.Z. Branco and by CNPq 
research grants to C.C.Z. Branco (520257/01-4) and L.H.Z. Branco (300128/97-5). We are grateful to Margarida G. Rauen, Unicentro, for reviewing the English and Jefferson L. Pereira and Maria Helena Carabolante, Unesp, for their help in the laboratory analyses.

\section{References}

BENENATI, P.L., SHANNON, J.P. \& BLINN, D.W. 1998. Desiccation and recolonization of phytobenthos in a regulated desert river: Colorado River at Lees Ferry, Arizona, USA. Regulated Rivers: Research and Management. 14:519-532.

BRANCO, L.H.Z. \& NECCHI JÚNIOR, O. 1997. Seasonality of macroalgae in three tropical drainage basins in São Paulo State, southeastern Brazil. Archiv für Hydrobiologie 141:75-91.

BRANCO, C.C.Z. \& NECCHI JÚNIOR, O. 1998a. Microhabitat and morphometric variation of two Chaetophoraceae (Chaetophorales, Chlorophyta) species in tropical streams of southeastern Brazil. Phycological Research 46:169-174.

BRANCO, L.H.Z. \& NECCHI JÚNIOR, O. 1998b. Distribution of stream macroalgae in three tropical drainage basin of southeastern Brazil. Archiv für Hydrobiologie 142:241-256.

DIGBY, P.G.N. \& KEMPTON, R.A. 1987. Multivariate analysis of ecological communities. Chapman \& Hall, London.

FISHER, S.G. 1983. Succession in streams. In Stream ecology: application and testing of general ecological theory (J.R. Barnes \& G.W. Minshall, eds.). Plenum Press, New York, p. 7-27.

FISHER, S.G., GRAY, L.J., GRIMM, N.B. \& BUSCH, D.E. 1982. Temporal succession in a desert stream ecosystem following flash flooding. Ecological Monographs 52:93-110.

GHOSH, M. \& GAUR, J.P. 1998. Current velocity and the establishment of stream algal periphyton communities. Aquatic Botany 60:1-10.

GORDON, N.D., MCMAHON, T.A. \& FINLAYSON, B.L. 1992. Stream hydrology, an introduction for ecologists. John Wiley \& Sons, Chinchester.

HORNER, R.R. \& WELCH, E.B. 1981. Stream periphyton development in relation to current velocity and nutrients. Canadian Journal of Fisheries and Aquatic Sciences 38:449-457.

KREBS, C.J. 1989. Ecological methodology. Harper \& Row, New York.

LAKE, P.S. 2000. Disturbance, patchiness and diversity in streams. Journal of the North American Benthological Society 19:573-592.

LAMBERTI, G.A., GREGORY, S.V., ASHENAS, L.R., WILDMAN, R.C. \& MOORE, K.M.S. 1991. Stream ecosystem recovery following a catastrophic debris flow. Canadian Journal of Fisheries and Aquatic Sciences 48:196-208.
LOCK, M.A., WALLACE, R.R., COSTERTON, J.W., VENTULO, R.M. \& CHARLTON, S.E. 1984. River epilithon: toward a structural-functional model. Oikos 42:10-22.

McCORMICK, P.V. \& STEVENSON, R.J. 1991. Mechanisms of benthic algal succession in lotic environments. Ecology 72:1835-1848.

NECCHI JÚNIOR, O. 1993. Distribution and seasonal dynamics of Rhodophyta in the Preto River basin, southeastern Brazil. Hydrobiologia 250:81-90.

NECCHI JÚNIOR, O. \& PASCOALOTO, D. 1993. Seasonal dynamics of macroalgal communities in the Preto River basin, São Paulo, southeastern Brazil. Archiv für Hydrobiologie 129:231-252.

NECCHI JÚNIOR, O., BRANCO, C.C.Z., SIMÕES, R.C.G. \& BRANCO, L.H.Z. 1995a. Distribution of stream macroalgae in northwest region of São Paulo State, southeastern Brazil. Hydrobiologia 299:219-230.

NECCHI JÚNIOR, O., BRANCO, L.H.Z. \& BRANCO, C.C.Z. 1995b. Comparison of three techniques for estimating periphyton abundance in bedrock streams. Archiv für Hydrobiologie 134:393-402.

ROBINSON, C.T., RUSHFORTH, S.R. \& BURGHERR, P. 2000. Seasonal effects of disturbances on a lake outlet algal assemblage. Archiv für Hydrobiologie 148:283-300.

SHEATH, R.G. \& BURKHOLDER, J. 1985. Characteristics of soft water stream in Rhode Island. II: Composition and seasonal dynamics of macroalgae communities. Hydrobiologia 128:109-118.

SOKAL, R.R. \& ROHLF, F.J. 1981. Biometry. W.H. Freeman, New York.

SOUTHWOOD, T.R.E. 1978. Ecological methods with particular reference to the study of insect population. Chapman \& Hall, New York.

STEINMAN, A.D. \& McINTIRE, C.D. 1986. Effects of current velocity and light energy on the structure of periphyton assemblages in laboratory streams. Journal of Phycology 22:352-361.

STEINMAN, A.D., MULHOLLAND, P.J. \& HILL, W.R. 1992. Functional responses associated with growth form in stream algae. Journal of the North American Benthological Society 11:229-243.

TILMAN, D. 1994. Community diversity and succession the roles of competition, dispersal, and habitat modification. In Biodiversity and Ecosystem Function (E.D. Schulze \& H.A. Money, eds.). Springer-Verlag, Berlin, p. 327-344.

UEHLINGER, U., HEINRICH, B. \& REICHERT, P. 1996. Periphyton dynamics in a flood prone river: evaluation of significant processes by modeling. Freshwater Biology 36:249-263.

WHITFORD, L.A. 1960. The current effect and growth of fresh-water algae. Transactions of the American Microscopical Society 79:302-309. 